\title{
ЗАГАЛЬНОТЕОРЕТИЧНА ЮРИСПРУДЕНЦІЯ: ТРАДИЦІї ТА НОВАЦІЇ ОДЕСЬКОЇ НАУКОВО-ПЕДАГОГІЧНОЇ ШКОЛИ ЮРІЯ МИКОЛАЙОВИЧА ОБОРОТОВА
}

Bcmyn.

У юридичній літературі викладено різні наукові позиції вчених щодо бачення майбутнього загальної теорії держави та права. Зважаючи на дуалістичність іiі предмету, сформувалися дві протилежні позиції: одні пропонують обмежитися тільки правом і державу розглядати лише в юридичному контексті як суб'єкт права в усьому розмаїтті його проявів; інші дотримуються позиції, що держава має залишитися у сфері загальнотеоретичного осмислення, причому бажано формувати загальнотеоретичну науку, яка б охоплювала і державу, і право як взаємопов'язані та соціально зумовлені явища. Усі інші позиції розташовуються в діапазоні між цими підходами.

Багатоманітність позицій проявляються певною мірою і в назвах дисципліни: «Загальна теорія права і держави», «Загальна теорія права», «Загальнотеоретична юриспруденція» тощо. Питаннями, які залишаються невирішеним за будь-яких підходів, є питання щодо того, яка дисципліна і в якому форматі має досліджувати державу; чи є вона взагалі предметом якоїсь однієї дисципліни; у яких площинах, ракурсах, аспектах досліджується держава тими чи іншими дисциплінами, яка 3 них здійснює синтез всього соціально-гуманітарного знання і чи такий синтез потрібний і необхідний; чи може мати той або інший підхід національні корені; чи бажано формувати загальне бачення для всіх країн, чи бачення держави повинно бути в основі загальним, а особливі та унікальні властивості конкретної держави задаються національним забарвленням.

Друга проблема - проблема розуміння тієї сукупності знань, у якій формується образ права і держави. Це тільки наукові знання чи наукові, освітні та практичні? Чи містять у собі системи знань про право і державу лише наукові складові, чи вони так само включають міфи, вірування тощо? А звідси витікає й питання: яким терміном у тому чи іншому варіанті вона повинна позначатися - юридична наука, правознавство, юриспруденція? 
Третя група проблем пов'язана $з$ реаліями тієї чи іншої країни чи групи споріднених країн, тими традиціями, соціальними, культурними, політичними, економічними та іншими умовами, що склалися в них, національними традиціями вирішення подібних питань в інших сферах соціально-гуманітарного знання; з недостатністю наявних знань, перспектив їх подальшого розвитку, можливостями сприйняття новел тієї чи іншої позиції науковою спільнотою тощо.

Четверта група проблем стосується перспектив розвитку як юридичної науки, так і освітнього процесу. Це, зокрема, вивчення досвіду організації науки в інших країнах, реалізація програми «Горизонт-2020», поєднання науки й освіти, координація наукових досліджень, їх фінансування, питання подальшого реформування юридичної освіти, співвідношення фундаментальних і прикладних досліджень, теоретичного та практичного навчання тощо.

Такий перелік питань можна продовжувати; їх аналіз виходить за межі цієї публікації, але між тим окреслює «поле», у межах якого існує підхід до їх вирішення, запропонований одеською науково-педагогічною школою загальнотеоретичної юриспруденції, представники якої позиціонують їі як варіант сучасної теорії держави і права. ІІї основні особливості пов'язані з дослідженням традицій і новацій правового та державного розвитку, затвердженням плюралістичної парадигми, відмовою від європоцентризму і етноцентризму, проголошенням принципу множинності правових культур, загостренням уваги на правовому менталітеті та правовому мисленні як найважливіших правових складових буття суспільства й індивіда, формуванням постмодерністських моделей державної і правової систем, що визначають стратегію державного та правового розвитку України.

Сьогодні можна констатувати, що в зазначеній вище проблемній сфеpi, яка здебільшого іншими вченими дискутувалася, але не знайшла розгорнутого бачення, реалізації в наукових дослідженнях та освітянській практиці, бачення зазначених проблем в цій науково-педагогічній школі не тільки знайшло теоретичне обгрунтування, деталізацію у відповідних наукових дослідженнях, але й було запроваджено в навчальний процес у вигляді навчальних дисциплін і спеціальних курсів, їх навчально-методичного забезпечення, власне педагогічної практики. Наприклад, викладання такої дисципліни, як «Загальнотеоретична юриспруденція», дає можливість саме на освітній практиці виявити ефективність такого підходу, порівняти з тими підходами, які існували в Одеській школі права в минулому, а також з підходами в інших вищих закладах освіти в Україні та інших країнах.

Необхідно окремо наголосити, що ця школа $є$ саме науково-педагогічною, адже вона виділяється з-поміж інших не тільки особливостями наукового бачення теорії держави і права, але й запровадженням наукових досліджень в освітянську практику, нерозривністю та взаємовпливами науки й освіти. Девізом цієї школи є «традиції та новації», і він реалізу- 
ється не тільки в наукових і педагогічних пошуках, а й власне у «житті» самої школи, іï становленні та розвитку, що проглядається уже на рівні збереження тих традицій, як складалися та існують в Одеській юридичній академії.

Становлення науково-педагогічної школи загальнотеоретичної юриспруденції.

Сучасна науково-педагогічна школа загальнотеоретичної юриспруденції є спадкоємцем наукової школи видатного вченого-юриста і письменника, корифея вітчизняної теорії та історії держави і права, доктора юридичних наук, професора, заслуженого діяча науки та техніки України Олексія Васильовича Сурілова, який заснував відому за межами України та СРСР наукову школу, що сприяла професійному становленню 27 кандидатів и 5 докторів юридичних наук, а серед них 6 представників Германії, Йорданії, Непалу, Афганістану, Йомену. Професор О.В. Сурілов очолював кафедру теорії та історії держави і права спочатку в Одеському державному університеті імені I.I. Мечникова, а потім в Одеській національній юридичній академії протягом 30 років (з 1968 р по 1998 р.). Наукові здобутки, педагогічний авторитет і особисті якості багато в чому визначили розвиток як кафедри теорії держави і права, так і наукової школи загальнотеоретичної юриспруденції. Зокрема, не втрачають свого вПливу його наукові розробки щодо національної державності, гносеологічної функції загальної теорії держави і права, іiі структури, автономності, методології правознавства, загальних питань теорії держави і права та інші.

Збереження та розвиток теоретичних і методологічних ідей О.В. Сурилова сьогодні здійснюється у формі наукових конференцій. Так, традиційним стало проведення спільної з юридичним факультетом Львівського національного університету імені Івана Франка Всеукраїнської наукової конференції молодих вчених, аспірантів і студентів «Актуальні проблеми теорії та історії прав людини, права і держави», присвяченої пам'яті видатних учених-юристів П.О. Недбайла, О.В. Сурілова, В.В. Копейчикова, яка 32012 року набула статусу міжнародної; проводяться й тематичні конференції, присвячені розвитку методології сучасної юриспруденції, іiі філософським аспектам, галузевим тенденціям розвитку тощо. Непересічне значення має використання теоретичних, методологічних і педагогічних розробок О.В. Сурілова в наукових дослідженнях, науковому забезпеченні освітнього процесу, підготовці науково-педагогічних кадрів, формуванні у них сучасного юридичного мислення тощо.

Нова віха в становленні освітньо-наукової школи загальнотеоретичної юриспруденції розпочалася у 1999 р., коли відбулося розділення кафедри теорії та історії держави і права Одеської національної юридичної академії і новостворену кафедру теорії держави і права очолив Юрій Миколайович Оборотов, який розпочинав свою наукову і педагогічну діяльність під впливом О.В. Сурилова та М.П. Орзіха. Представниками цієї школи вважають себе понад 40 науковців і педагогів, серед яких 6 
докторів и 27 кандидатів наук. Коло їхніх наукових інтересів охоплює загальнотеоретичну юриспруденцію як загальний напрям досліджень, а також ї концептуалізацію, конкретизацію на цій основі окремих теоретичних проблем державного та правового розвитку та визначення шляхів ї наукового розв'язання.

Важливою віхою у становленні школи загальнотеоретичної юриспруденції було відповідне перейменування кафедри теорії держави і права, яке було схвалене Вченої радою Національного університету «Одеська юридична академія» 8 квітня 2016 р. Це стало не лише підтвердженням важливості ідей загальнотеоретичної юриспруденції для юридичної університетської освіти, але й вагомим фактором інституціоналізації цієї школи як впливового центру вітчизняної юридичної науки.

Напрями досліджень освітньо-наукової школи загальнотеоретичної юриспруденції.

Важливою ідеєю школи загальнотеоретичної юриспруденції, очолюваної Ю.М. Оборотовим, є методологічний плюралізм, що зумовлює множинність напрямів досліджень з боку іï представників. Так, загальнотеоретичне бачення юриспруденції розробляється в контексті інших юридичних і неюридичних наук у зв'язку з реальними проблемами розвитку держави і права, зокрема у зв’язках з філософією права (Ю.М. Оборотов, В.В. Завальнюк, В.В. Дудченко, А.Ф. Крижановський, К.В. Горобець) антропологією права (В.В. Завальнюк), аксіологією права (К.В. Горобець), герменевтикою права (В.В. Дудченко), методологією юриспруденції (Ю.М. Оборотов, А.Ф. Крижановський, Н.М. Крестовська, К.В. Горобець, О.С. Мельничук), культурологією права (А.П. Овчиннікова), історією правової думки (Н.М. Крестовська, А.В. Дзевелюк, A.I. Кормич). Міждисциплінарний статус досліджень, що проводяться в межах цієї школи, створює передумови для їі розвитку як відкритої до нових ідей та концепцій, адаптивної до новітніх умов існування права та держави. Також це надає можливість дослідникам не обмежуватися винятково уявленнями про правову раціональність і здійснювати науковий пошук у тих сферах соціальної науки, які мають суміжний з юриспруденцією статус.

На основі концептуального бачення, мети і завдань, особливостей загальнотеоретичної юриспруденції розробляються такі фундаментальні проблеми:

- методології права і держави (Ю.М. Оборотов), теорії сучасної держави (О.О. Джураєва, В.В. Тароєва, В.А. Федоров), інституціоналізаціі громадянського суспільства та правової держави (А.I. Кормич), інституціоналізації державної влади (С.В. Ковбасюк), взаємодії держави і церкви (I. А. Бальжик);

- змісту та типології праворозуміння (Ю.М. Оборотов, К.В. Горобець), правового плюралізму (В.В. Дудченко, О.С. Мельничук);

- спеціальних або предметних теорій загальнотеоретичної юриспруденції: теорії правового порядку (А.Ф. Крижановський), теорії право- 
вих режимів (П.П. Богуцький), теорії міського права (О.С. Мельничук), теорії правової культури (С.М. Скуріхін), загальної теорії договору (3.М. Юдін);

- загальнотеоретичних підвалин окремих правових феноменів та їх взаємозв'язків: правових аномалій (Г.М. Чувакова), правової допомоги (В. С. Личко), слов'янського права (М.Ю. Рязанов), локального правового регулювання (В.В. Форманюк), правового міфу (Ю.В. Тіщенко), правового статусу діаспори (Т. М. Фурдик), взаємодії національного та міжнародного права (О.М. Іванченко), мови права та національної юридичної термінології (С.П. Кравченко);

- історії одеської школи права (Л.П. Арнаутова);

- особливостей теоретичного осмислення ювенального права та ювенальної юстиції (Н.М. Крестовська), церковного права (І.А. Бальжик), воєнного права (П.П. Богуцький, С.М. Скуріхін).

Наукова школа виходить за межі тільки кафедри загальнотеоретичної юриспруденції Національного університету «Одеська юридична академія»: теоретичні положення, які сформовані в концепції загальнотеоретичної юриспруденції, були сприйняті й представниками інших кафедр як академії, так і вищих навчальних закладів України, практикуючими юристами, дослідниками різних наукових спеціалізації (С.К. Могил, С.В. Джолос, В.М. Кравчук, Р.А. Бірюков, Н.Б. Арабаджи та інші).

«Родзинкою» школи загальнотеоретичної юриспруденції $є$ «традиційний» аспект становлення цієї науково-педагогічної інституції. Так, за наукового консультування професора Ю.М. Оборотова захищено докторські дисертації: «Традиція правового плюралізму: західна та східна інтерпретація» (В.В. Дудченко, 2007), «Правові засоби викорінення гендерного насильства в Україні: історико-теоретичний аналіз» (Н.В. Аніщук, 2008), «Ювенальне право України: генезис і сучасний стан» (Н.М. Крестовська, 2008), «Правовий порядок суверенної України: становлення та тенденціï розвитку (загальнотеоретичне дослідження)» (А.Ф. Крижановський, $2009)$, «Правова нормативність в умовах становлення та розвитку українського права: загальнотеоретичне дослідження» (Л.І. Заморська, 2014), «Міська правова система в Україні: загальнотеоретичне дослідження» (О.С. Мельничук, 2016).

Сьогодні ці доктори наук не тільки підтверджують свою належність до школи загальнотеоретичної юриспруденції, розвивають іiі своїми дослідженнями, але й забезпечують науково-педагогічну підготовку нових представників цієї школи. Зокрема, за наукового керівництва Ю.М. Оборотова, В.В. Дудченко, А.Ф. Крижановського, Н.М. Крестовської підготовлено та захищено такі кандидатські дисертації: «Мова як фактор правоутворення та законотворення» (С.П. Кравченко, 2000), «Місцеве самоврядування м. Одеси в середині XIX століття: історико-правове дослідження» (С.М. Стременовський, 2000), «Сучасна держава в екстремальних ситуаціях: нормативи; органи; функції» (С.К. Могил, 2003), «Право і держава в концепції правосвідомості I.О. Ільїна» 
(О.С. Мельничук, 2005), «Функції сучасної держави» (О.О. Джураєва, 2006), «Темпоральні характеристики права в Україні» (І. Г. Оборотов, 2008), «Військове право в системі права України» (П.П. Богуцький, 2009), «Просторове буття держави» (І.В. Долматов, 2009) «Правові традиції України» (С. С. Павлов, 2010), «Держава в етатистському вимірі: загальнотеоретичний аспект» (С. В. Джолос, 2011), «Інститути контрольної влади в сучасній Україні» (В.В. Тароєва, 2011), «Правова культура офіцерського складу Збройних Сил України» (С.М. Скуріхін, 2011), «Аксіосфера права та ії компоненти» (К.В. Горобець, 2012), «Поняття та види локальних правових актів» (В.В. Форманюк, 2013), «Правопорядок як цінність: загальнотеоретичне дослідження» (Н. Б. Арабаджи, 2013), «Догма права у сучасній юриспруденції: загальнотеоретичне дослідження» (О.М. Сидоренко, 2013), «Економічні виміри правопорядку: теоретико-правове дослідження» (Л.В. Шонія, 2015), «Правове регулювання діяльності юридичних клінік в Україні» (М.Т. Лоджук, 2014), «Право і література» як напрям юриспруденції: за творами М.О. Булгакова» (Ю.В. Хижняк, 2014), «Правовий міф і правова міфотворчість як атрибути сучасного суспільства» (Ю.В. Тіщенко, 2014), «Боргова функція сучасної держави» (В.В. Федоров, 2015), «Правове положення діаспори: загальнотеоретичне дослідження» (Т.А. Фурдик, 2015), «Інформаційна функція українського права» (I.В. Антошина, 2016) і багато інших.

Подібна циклічність притаманна й науковому баченню загальнотеоретичної юриспруденції, яке тісно пов'язано з освітнім процесом та практикою, їх взаємозв'язками, переходами від одного до другого і навпаки. Так, певною мірою (спрощуючи) зародження й оприлюднення ідеї загальнотеоретичної юриспруденції слід пов'язувати з першими науковими статтями та доповідями, виступами на наукових конференціях, у яких насамперед здійснювалися спроби описати результати досліджень стану розвитку теорії держави і права, виокремити коло невирішених проблем, визначити шляхи їх можливого розв'язання і таке інше.

Підвалини майбутньої концепції загальнотеоретичної юриспруденції Ю.М. Оборотовим закладалися ще у 80-90-х роках. Його наукові розробки того часу стосувалися ціннісного виміру права (1984), історичного, політологічного та цивілізаційного бачення держави $(1988,1990,1991$, 1993, 2002), філософських аспектів іiі осмислення (1994), властивостей України як сучасної держави (1995) та їх осмислення (1996), прогресу в праві (1997), етапів розвитку права (1999), національної правової культури $(1999,2000)$, юридичної освіти (1999), євразійської правової сім’і (2000), юридичної антропології (2000), герменевтичного методу (2000), держави, права, юридичної освіти та їх осмислення в епоху постмодерну $(2002,2003)$. Систематизація авторських поглядів і підходів відносно сучасної держави та іiі теоретичного бачення була здійснена Ю.М. Оборотовим у навчальних курсах «Основи сучасної держави» (1995) і «Сучасна держава: основи теорії» (1998). 
Підсумком здійснених наукових досліджень, їх синтезом, переосмисленням, виявленням прогалин тощо, а також фундаментальною основою концептуалізації загальнотеоретичної юриспруденції для цієї школи стали монографії Ю.М. Оборотова «Традиції та новації в правовому розвитку» (2001) і «Традиції та оновлення в правовій сфері (від пізнання до осягнення права)» (2002), у яких було окреслено контексти подальшого розвитку, основні складові концепції загальнотеоретичної юриспруденції, визначено можливі аспекти, ракурси, філософські, теоретичні, методологічні та інші основи (засади), а опублікування монографій надало можливість науковій спільноті ознайомитися з ними, обговорити дискусійні питання, виявити інші шляхи розв'язання проблем розвитку загальної теорії держави і права. Авторська концепція бачення загальнотеоретичної юриспруденції набула офіційного, публічного визнання в результаті захисту Ю.М. Оборотовим докторської дисертації «Традиції та новації в правовому розвитку: загальнотеоретичні аспекти» (2004).

Проте не тільки в працях Ю.М. Оборотова, але й під їх впливом розвивалися концептуальні засади загальнотеоретичної юриспруденції іншими iï прихильниками. Так, В.В. Дудченко досліджувала філософські аспекти загальнотеоретичної юриспруденції в контексті герменевтики та феноменології права, трансцендентності західної традиції права (2003), правової реальності, історії ідеї права (2004), плюралізму концептуалізацій права та такі його властивості, як легітимність і легальність, універсалізм, партикуляризм і фактичність (2005), проблеми порівняльного правознавства та плюралістичності правової карти світу (2006), результати яких було систематизовано викладено в таких виданнях, як «Правничий довідник для професійних суддів» (2003), «Вступ в українське право» (2005), монографіях «Традиція правового розвитку: плюралізм правових вчень» (2006), дисертаціях на здобуття наукового ступеня доктора юридичних наук «Традиція правового плюралізму: західна та східна інтерпретація» (2007).

Н.М. Крестовська теоретичні основи та методологічні підходи загальнотеоретичної юриспруденції використала і адаптувала для дослідження проблематики ювенального права, зокрема особливостей становлення ювенального права, його структури та принципів (2001), перспектив ювенальної юстиції та міжнародних стандартів прав дитини (2002), порівняння ювенального права і ювенальної юстиції в США та Україні, концепції навчальної дисципліни «Ювенальне право» (2003), функцій ювенального права, зокрема охорони прав дитини, відповідного європейського досвіду (2003-2005), ювенального проступку та ювенальної відповідальності (2004), кримінальної відповідальності неповнолітніх (2005-2006), джерел ювенального права, його місця в системі права України, співвідношення міжнародного, регіонального та національного його компонентів, а також ювенальної політики, ювенального права та ювенальної юстиції (20062007), просторового та аксіологічного вимірів дитинства (2006-2008), принципів ювенального права України, підстав виокремлення ювеналь- 
ного права як галузі (2008) тощо. Теоретико-історична концептуалізація вітчизняного ювенального права була завершена в монографії «Ювенальне право України: генезис та сучасний стан» (2008) і в дисертації на здобуття наукового ступеня доктора юридичних наук «Ювенальне право України: генезис та сучасний стан» (2008).

А.Ф. Крижановський основою своїх різноманітних наукових пошуків обрав таку «предметну» сферу загальнотеоретичної юриспруденції, як правопорядок, який він осмислював у зв'язку з громадянським суспільством (2000), правовим життям Стародавнього Риму (2003), соціальним порядком (2004), інтеграційними правовими системами (2005), правовою політикою, законністю, правозахисною діяльністю, адміністративним порядком (2007), трансформаційними процесами, громадським і державним порядком (2008) тощо. Осмислення правопорядку здійснювалося 3 використання філософських підходів: феноменології (2004-2005), аксіології (2008), адаптації методології юриспруденції стосовно особливостей правопорядку як правового феномену, а також іiі трансформації в епоху постмодерну з метою формування його концептуального бачення (20062008). Цілісного бачення авторська концепція правопорядку дістала в монографіях «Феноменологія правопорядку: поняття, виміри, типологія» (2006), «Правовий порядок в Україні: витоки, концептуальні засади, інфраструктура» (2009) і дисертації на здобуття наукового ступеня доктора юридичних наук «Правопорядок суверенної України: становлення та тенденції розвитку (загальнотеоретичне дослідження» (2009). Інші аспекти загальнотеоретичної юриспруденції А.Ф. Крижановський досліджував у контексті основ сучасної держави, правової свідомості, прав людини, процесів глобалізації та інтеграції, процесуального та ювенального права, реформи юридичної освіти, правосуддя, професіоналізму в юридичній сфера та інших.

Сфера наукових розвідок В.В. Завальнюка в царині загальнотеоретичної юриспруденції окреслюється переважно проблемами й аспектами антропології права, а також філософськими, теоретичними, методологічними засадами iі осмислення. Розгортання авторської концепції антропології права здійснювалося в аспекті осмислення ролі та значення історизму в юридичній науці (1998-2001), з'ясування властивостей юридичної антропології як науки (2007), іiі наповнення людиновимірністю та правами людини $(2008,2009)$, дослідження генезису антропологічних знань $(2009,2013)$ і ролі антропології в сучасному правовому розвитку та пізнанні правової реальності, судового плюралізму (2009), значення та особливості антропологічного виміру для розуміння взаємодії права і суспільства $(2009,2010)$, правової політики України (2010), цивілістичних досліджень (2011), реформування системи вищої освіти, визначення особливостей концептуалізації антропологічної парадигми права, iii зумовленості глобалізаційними процесами, традиціями та ментальністю українського народу (2012), пов'язаності з феміністичною та гендерною юриспруденцією (2012-2013), соціоцентричною парадигмою права 
(2013), міфами права та правовою культурою (2013, 2015), правозначущою поведінкою (2013), а також в аспекті аналізу правових систем і правових традицій (2013-2014).

Прихильне ставлення науково-педагогічної спільноти до теоретичного і методологічного потенціалу здійснених представниками цієї школи концептуалізацій загальнотеоретичної юриспруденції та іiі складових щодо іiі проблемних питань, варіантів інших підходів, ніж запропоновані ними, тощо виявлялося в процесі наукових дискусій на захисті відповідних дисертацій, сформульовано у відгуках офіційних опонентів на дисертації та відгуках на автореферати дисертацій, подано в рецензіях на монографії та підручники, може бути з'ясовано в більш значних обсягах в результаті аналізу результатів використання положень і висновків концепції загальнотеоретичної юриспруденції в працях інших дослідників.

Так, під час захисту дисертацій грунтовне осмислення цих питань здійснено такими відомими вченими, як доктор юридичних наук, професор, академік Національної академії правових наук України М.В. Цвік; доктор юридичних наук, професор В.Д. Бабкін, доктор юридичних наук, професор А.А. Козловський; доктор юридичних наук, професор, член-кореспондент Національної академії правових наук України М.I. Козюбра; доктор юридичних наук, професор, академік Національної академії правових наук України П.М. Рабинович; доктор юридичних наук, професор, член-кореспондент Національної академії правових наук України В.В. Лемак та інші.

Принципово важливо ще раз підкреслити, що наукові дослідження представників цієї школи безпосередньо втілювалися в навчальний процес через підручники, посібники як з теорії держави та права, так і 3 історії вчень про державу і право, з інших навчальних дисциплін, а також через різноманітні навчально-методичні матеріали для студентів різних рівнів професійної підготовки та форм навчання. Так, за 2000-2015 роки видано: «Основы государства и права: пособие для абитуриентов» / Н.Н. Крестовская, А.Ф. Крыжановский (2000); «Теория и философия права: пособие для подготовки к государственному экзамену по специальности «Правоведение» / Н.П. Крестовская, А.Ф. Крыжановский, Л.Г. Матвеева, Оборотов Ю.М. (2001); «Теорія держави і права. Правничий довідник для професійних суддів» / Ю.М. Оборотов, В.В. Дудченко (2003); «Теория государства и права в вопросах и ответах. Государственный экзамен: учебно-методическое пособие» / Ю.М. Оборотов, А.Ф. Крижановский, Н.Н. Крестовская, Л.Г. Матвеева (2004); «Правничий довідник для професійних суддів» / Ю.М. Оборотов, В.В. Дудченко (2005); «Ювенальна юстиція: навч. посібник» / А.І. Гусєв, Ю.Б. Костова, Н.М. Крестовська, T.Є. Семікоп, В.I. Шмеріга, І.Г. Терещенко; за ред. Н.М. Крестовської (2006); «Основи римського приватного права: навч.-метод. посібник» / Н.М. Крестовська, І.С. Канзафарова» (2006); «Теорія держави і права: метод, матеріали для студ. 1-го курсу» / Ю.М. Оборотов, Н.М. Крестовська, А.Ф. Крижановський (2007); «Теорія держави і права: державний 
іспит» / Ю.М. Оборотов, А.Ф. Крижановський, Н.Н. Крестовська (2007); «Проблеми теорії держави і права : метод, матеріали» / В.В. Дудченко, А.Ф. Крижановський» (2007); «Основи правознавства України» С.В. Ківалов, П.П. Музиченко, Н.М. Крестовська, А.Ф. Крижановський (2007); «Історія учень про державу і право: навч. посібник» / Н.М. Крестовська, О.Ф. Цвіркун (2008); «Теорія держави і права: Елементарний курс» / Н.М. Крестовська, Л.Г. Матвєєва. - 2-ге вид. (2008); «Основы правоведения Украины: учеб. пособ.» / С.В. Кивалов, П.П. Музыченко, Н. Н. Крестовская, А.Ф. Крижановский (2008); «Теорія держави і прави: методичні матеріали для студентів 1 курсу» / Ю.М. Оборотов, Н.Н. Крестовская, Е.А. Джураева (2010); «Теорія держави і права. Державний іспит» / Ю.М. Оборотов, А.Ф. Крижановский, Н.Н. Крестовская, Л.Г. Матвеева (2011); «Підготовка курсових робіт з теорії держави і права : методичні рекомендації для юридичного коледжу» / Ю.М. Оборотов, В.В. Тароєва (2012); «Теорія держави і права: методичний посібник» / Ю.М. Оборотов, К.В. Горобец, Н.Н. Крестовская (2013); «Проблеми теорії держави і права: навч.-метод. посіб. для студ.-магістрів» / Ю.М. Оборотов, К.В. Горобець (2014).

Розвиток наукових досліджень у цій царині, аналіз нових аспектів, проблем і шляхів їх вирішення, з одного боку, не тільки дали змогу, а й буквально вимагали їх нового осмислення, систематизації, а з іншого - 3 метою запровадження наукових досліджень у навчальний процес, поєднання науки, освіти і практики відповідним чином змінили й методику викладання теорії держави і права, іiі навчально-методичне забезпечення.

Особливістю науково-педагогічної школи $є$ й те, що іï представники активно залучені до організації навчально-наукового процесу в академії та за іï межами. Так, професор В.В. Завальнюк $є$ ректором Національного університету «Одеська юридична академія», професор А.Ф. Крижановський очолює Міжнародний гуманітарний університет, професор В.В. Дудченко є вченим секретарем Вченої ради академії, доцент С.П. Кравченко керує факультетом заочного навчання Національного університету «Одеська юридична академія», а доцент С.М. Скуріхін завідує кафедрою військової підготовки.

Завдяки ініціативності та організаційним зусиллям представників науково-педагогічної школи тільки за останні п'ять років було проведено низку наукових заходів всеукраїнського та міжнародного масштабу: Міжнародну конференцію «Актуальні проблеми філософії права (правова аксіологія)» (2011), Міжнародний круглий стіл «Актуальні проблеми філософії права: аксіосфера права і держави» (2012), міжнародні наукові конференції, присвячені пам'яті професора О.В. Сурілова «Удосконалення методології сучасної юриспруденції» (2012, 2013, 2014, 2015).

3 метою формування в студентів сучасного юридичного світогляду, бачення плюралістичної картини правового світу, сприйняття досягнень юридичної науки та практики різних країн світу, опанування ними іншомовної юридичної термінології запроваджено в освітній процес викладан- 
ня англійською мовою таких навчальних дисциплін, як "Legal Philosophy" i "History of Political and Legal Doctrines" (Н.M. Крестовська, О.С. Мельничук, К.В. Горобець, М.Ю. Рязанов), а французькою - "L’initiation a la thйorie juridique contemporaine" (К.В. Горобець).

Одним із важливих науково-педагогічних напрямів діяльності школи $€$ організація та розвиток різних видів наукової діяльності студентів, їх залучення до опанування ними актуальних загальнотеоретичних аспектів розвитку держави і права. Викладачі кафедри загальнотеоретичної юриспруденції активно залучені до наукового керівництва дослідженнями студентів. Важливого значення надається й функціонуванню дискусійних клубів «Ораторське мистецтво» та «Право і цивілізація», у яких беруть участь студенти та аспіранти Національного університету «Одеська юридична академія».

Визнання наукових і педагогічних досягнень цієї школи виявляється й у тому, що іï представники неодноразово відзначалася почесними нагородами і званнями. Засновнику школи, завідувачу кафедри, доктору юридичних наук, професору Ю.М. Оборотову надані почесні звання «Заслужений юрист України», «Відмінник освіти», орден «За заслуги» III ступеня, а в 2010 році він був обраний членом-кореспондентом Національної академії правових наук України. Професорів В.В. Завальнюка та В.В. Дудченко, доцента П.П. Богуцького відзначено наданням почесного звання «Заслужений юрист України». Професор А.П. Овчинникова є почесним членом Спілки театральних діячів України. Професор А.Ф. Крижановський обраний членом-кореспондентом Національної академії правових наук України, і йому надане почесне звання Заслуженого діяча науки і техніки України. Представники школи неодноразово нагороджувалася почесними грамотами Президента НУ «ОЮА» академіка С.В. Ківалова.

Методологічні та наукознавчі засади концепиії загальнотеоретичної юриспруденції.

Сучасна юридична наука покликана широко використовувати творчість і креативність, оскільки знаходиться в умовах, коли право і держава перебувають в стані таких змін, які тягнуть за собою не лише виникнення нових сфер юриспруденції, але й зміну змісту і наповнення наук, які до неї входять. Надактуальними для наукових досліджень стають активні процеси зростання рухомості (плинності) догми права і поглиблення кризи держави, що викликає необхідність новацій у самій юриспруденції.

Зазначимо, що перехід від терміну «юридична наука» до терміну «юриспруденція» пояснюється появою в правовій сфері напрямів пізнання, які складно констатуються як наукові (наприклад, філософія права), а також подоланням юриспруденцією надлишкової раціональності, виходом до сфери нераціонального, наповнення професійної юридичної діяльності духовним змістом і вірою в право, визнанням та використанням соціальної та особистісної цінності права.

За допомогою положень та інструментарію загальнотеоретичної юриспруденції як фундаментальної складової частини юриспруденції в проце- 
сі професійної юридичної підготовки здійснюється «прищеплення» принципів права як ключових елементів професійної правової свідомості та правового мислення. Можна вважати, що становлення загальнотеоретичної юриспруденції відбувається вже за сучасної доби, паралельно змінам у людині, суспільстві, самій державі та праві, а також у їх теоретичному осмисленні в таких відомих формах, як енциклопедія права, теорія права, теорія держави і права, загальна теорія держави і права тощо.

Назва «загальнотеоретична юриспруденція» як навчальна дисципліна замість традиційної теорії держави і права не лише покликана подолати легковажні уявлення про роль теоретичної підготовки спеціалістів юридичного профілю, але й націлена на те, щоб закріпити, по-перше, первинність права щодо держави i, по-друге, вивести загальнотеоретичне знання в центр концепції сучасної юридичної освіти.

Тут важливими стають аргументи на користь нетотожності понять «юридична наука» i «юриспруденція», що зумовлено одразу кількома обставинами. По-перше, поняття «юриспруденція» є ширшим, оскільки воно охоплює не лише наукове знання про право і державу, яке має відповідати критеріям наукової раціональності (зокрема, таке знання має підлягати верифікації та фальсифікації), але й практичне знання. Недарма в багатьох мовах слово «юриспруденція» означає не лише науку про право, але й систему юридичної практики, зокрема судової. Таким чином, юриспруденція $є$ ширшою за юридичну науку змістовно. По-друге, юриспруденція, не будучи обмеженою критеріями наукової раціональності, може дозволити собі включати до свого поля ті напрями юридичних досліджень, які неможливо розглядати як наукові, зокрема філософію права, адже загальновідомо, що філософія лежить за межами наукової раціональності. Це дає змогу більш глибоко розкрити специфічні риси сучасного права та сучасної держави, виявити їх міфологічні підвалини, показати особливість їх образу в правосвідомості, який не завжди підлягає раціональному аналізу. Нарешті, по-третє, юриспруденція, на відміну від юридичної науки, існує в ширшому цивілізаційному контексті, що дає можливість більш чітко та послідовно впроваджувати одну з головних ідей Одеської школи права, а саме ідею правового плюралізму. I дійсно, досить складно говорити про юридичну науку в межах релігійного типу правових систем, але при цьому можна з упевненістю говорити про релігійну юриспруденцію. Таким чином, юриспруденція включає до себе набагато більш широке поле дослідницьких напрямів.

Отже, першою важливою методологічною та епістемологічною перевагою назви «загальнотеоретична юриспруденція» над назвою «теорія держави і права» $€$ те, що юриспруденція не обмежується суворими вимогами наукової раціональності.

Не менш важливою перевагою використання такої назви для навчальної та наукової дисципліни $є$ й те, що вона не передбачає моністичності в інтерпретації теоретичних засад права та держави. Сама назва «Теорія держави і права» (а також іiі варіації) вказує на те, що, по-перше, можли- 
ва якась одна всеосяжна теорія права і держави, яка в змозі пояснити усі прояви цих соціальних інститутів. У сучасних умовах це є вкрай сумнівним, особливо з урахуванням того, наскільки глибокою є прірва, наприклад, між теорією національного права та теорією міжнародного права. Принципова неможливість однієї теорії права неодноразово підкреслювалася багатьма відомими філософами права і теоретиками, оскільки право і держава є онтологічно плюралістичними явищами, а тому не видається можливим вироблення гносеологічно моністичного їх пояснення.

Понад те, сучасна теоретична юриспруденція представлена далеко не однією теорією, а включає до себе кілька десятків різноманітних теорій середнього рівня, як-от теорія правового порядку, теорія правової нормативності, теорія дії права, теорія правової поведінки, теорія правових відносин, теорія верховенства права тощо. Суто методологічно (а так само й методично) їх досить складно представити як складові частини однієї всезагальної теорії, що знову ж таки доводить більшу вдалість формулювання «загальнотеоретична юриспруденція», адже вона не обмежується лише загальними теоріями, а включає в себе також окремі теоретичні конструкції середнього рівня.

Назва «Загальнотеоретична юриспруденція» також дає змогу подолати одну з поширених і типових проблем - пріоритету права над державою чи навпаки. Часто можна зустріти судження щодо необхідності використання саме такої послідовності («право і держава») у формуванні навчальних курсів, хоча офіційний паспорт спеціальності 12.00.01 використовує прямо протилежний порядок. Так само дискусії точаться щодо того, яку частину слід вивчати першою - правову чи державну. Відзначимо, що проблема дуалізму об'єкту юриспруденції долається, якщо виходити з того, що тут право (правове) і держава (державне) об'єднуються в юриспруденції та предметно розгортаються за такими напрямами, як правознавство та державознавство. Юриспруденція як наука, на відміну від інших наук, які досліджують право та державу, розглядає ці явища в призмі взаємодії, взаємозумовленості та додатковості. Тому протиставлення права і держави, дискусії щодо першочерговості одного явища або іншого тут втрачають свій сенс.

Таким чином, загальнотеоретична юриспруденція з методологічної точки зору постає як набагато сучасніша й продуктивніша концепція, аніж теорія держави і права. Вона дозволяє розширити концептуальне поле теоретичного пошуку в правовій сфері, але при цьому зберегти ту традиційність, яка пов'язана з цією, безперечно, фундаментальною дисципліною.

Підручник «Загальнотеоретична юриспруденція» як фактор інституціоналізації освітньо-наукової школи.

Ознайомлення з концепцією загальнотеоретичної юриспруденції зумовило й вибір методики іiі аналізу, а саме дослідження нерозривності, взаємопов'язаності наукових, освітянських і прагматично орієнтованих текстів, певної циклічності домінування тих чи інших із них, які в свій 
основі ідентифікуються як теоретичні, але не обмежуються тільки теорією держави і права як науки чи наукової дисципліни, а також аналіз цих текстів як результат такої форми інституціоналізації наукових досліджень, як науково-педагогічна школа.

Передусім цей масив публікацій стосується теорії держави і права, плюралістичності ї бачення і як науки, і як навчальної дисципліни, яка має різні форми офіційної та неофіційної наукової чи освітянської систематизації та визнання іï як такої. На пострадянському просторі систематизація та офіційне визнання належності наукових досліджень до загальнотеоретичних здійснюється на підставі паспортів наукових спеціальностей, якщо мова йде про кваліфікаційні дослідження на здобуття наукових ступенів, або належності до тих чи інших кафедр, а відповідно, і дисциплін, які представниками цих кафедр викладаються і за якими присуджуються наукові звання. Проте i в одному, і в іншому випадку значення має як внутрішня систематизованість, так й зовнішня відокремленість наукових чи навчальних знань. Історично склалося, що в більшості країн до публікацій, які претендують на систематизований образ певного знання, переважно відносять підручники і посібники, що притаманно й Україні.

У наукознавстві недарма вважають, що найбільш цілісно та послідовно, логічно взаємопов'язано та в межах певної наукової позиції, зі збереженням традицій та акцентуації новацій у їх взаємозв'язку інформація подається саме в підручниках. Більше того, вони передбачають охоплення нормативно-правового матеріалу, правозастосовної та іншої правової практики, формування у студентів навичок і вмінь застосовувати теоретично набуті знання у практику, а також, навпаки, навичок i вмінь здійснювати наукове осмислення практики тощо.

Саме тому аналіз масиву публікацій із загальнотеоретичної юриспруденції як сучасного бачення теорії держави і права доцільно починати саме з підручників і навчальних посібників. За останні п'ять років викладачі кафедри опубліковали 20 підручників і посібників із дисциплін кафедри. Два підручники отримали гриф МОН України. I хоча більшість видань мали традиційну назву «теорія держави і права», але за змістом вони відбивали досить послідовну трансформацію від усталених підходів як традиції до нового концептуального бачення як новації - загальнотеоретичної юриспруденції, причому традиції зберігаються, але наповнюються новим змістом, а новації відкривають нові обрії, яких не було і не могло бути в традиціях. Це проглядається не тільки у введенні нових розділів, підрозділів, але й у наповненні традиційних змістовними та методологічними новелами.

У цьому контексті важливо зазначити: якщо, так би мовити, новелізація здійснюється за умов їх попереднього наукового забезпечення, то системне переосмислення матеріалу, адаптація до наукових положень, до особливостей навчальної літератури сприяє виявленню нових ракурсів, аспектів, прогалин, протиріч, неузгодженостей тощо, які можна виявити 
саме в процесі впорядкування всього матеріалу в межах певного колективного його бачення та надання йому внутрішньої узгодженості та розгорнутості.

Якщо перші підручники з теорії держави і права, які було розроблено викладачами кафедри теорії держави і права, в основному можна віднести до традиційного бачення теорії держави і права (а в той час іншого й не могло бути), то вже навчальний посібник відомого вченого-теоретика О.В. Сурилова (1983) відрізнявся від інших підручників описанням плюралізму проблем і багатоманітності шляхів їх вирішення, що орієнтувало студентів, а ще більше викладачів, серед яких цей посібник був надзвичайно популярним і цінованим, на з'ясування проблемних питань, аналіз різних наукових позицій вчених тощо.

Представники школи майже кожні два роки випускали нові редакціі підручників і посібників з теорії держави і права різного призначення для навчального процесу, проте кожна нова редакція, зберігаючи те, що витримало випробування часом, містила і новий матеріал. Окрім того, паралельно здійснювалися й наукові пошуки, результати яких реалізовувалися в навчально-методичних матеріалах, різного роду довідниках, рекомендаціях тощо. У цьому контексті слід відзначити посібник для суддів, у якому була реалізована спроба наблизити теорію держави і права в іï актуальному та проблемному баченні до реалій юридичної практики; такий підхід надалі став одним із напрямів концептуалізації загальнотеоретичної юриспруденції. Крім того, важливим для розвитку специфіки підходу Одеської школи права до теоретичних досліджень стало видання «Вступ до українського права» в 2005 році, яке було перевидане в розширеному варіанті в 2009 році та після того видане в англомовному варіанті в 2011 році.

Здається, багато в чому саме це і складало основу переходу до юриспруденції та іï теоретичного осмислення. Причому не на рівні прикладів, як це іноді буває, а на основі, по-перше, внутрішньої єдності, нерозривності юридичних науки, освіти, практики; по-друге, подолання дуалізму загальної теорії права як загальної теорії держави (не завжди тільки юридичної) і загальної теорії права (знову таки не тільки юридичної, яка здійснюється юристами, а в більш широкому форматі) у контексті не лише наукового бачення, а й реальної єдності державного і правового в суспільному житті, в результаті чого ненаукове $є$ панівним, а реальне основою, база для наукового, де освітянське є їх синтезом.

Уже в перших кафедральних підручниках із теорії держави і права зверталася увага на плюралізм розуміння держави і права, їх соціальну, культурну та національну або часову та просторову зумовленість, особливості теоретичного юридичного осмислення, значення методології ї пізнання, зв’язок з іншими науковими дисциплінами, юридичною практикою, реаліями державного та правового розвитку, сучасними світовими процесами тощо.

Логічним завершенням змін в розумінні ролі теорії держави і права в підготовці студентів стала концепція виводу права на основну роль у 
загальнотеоретичній юридичній підготовці. Формування мови права, правового мислення, сучасного праворозуміння, а також правотлумачення було закладено в основу підготовки кафедрального підручника «Загальнотеоретична юриспруденція» .

Приваблює саме те, що підручник «Загальнотеоретична юриспруденція» є результатом авторського, своєрідного, але еволюційного переосмислення теорії держави і права, яке здійснювалося протягом майже 15 років на основі відповідних наукових досліджень, з урахуванням реалій як організації та здійснення навчального процесу, результатів опанування теоретичних знань студентами, набуття ними практичних вмінь i навичок, освітянських реформ, так і особливостей державного і правового розвитку.

Саме цей підручник є базовим для організації та здійснення навчального процесу в академіі, а з іншого боку, він найбільш систематизовано та внутрішньо узгоджено не тільки відбиває сучасну концепцію загальнотеоретичної юриспруденції, але й окреслює нові напрями їі розвитку.

У цьому сенсі значною подією в еволюції одеської школи загальнотеоретичної юриспруденції стала підготовка та публікація колективного підручника «Загальнотеоретична юриспруденція: навчальний курс» (2011), який було затверджено Міністерством освіти, науки, молоді та спорту України (лист № 1/11-12162 від 22.12.2011р.) й авторами якого є відомі представники цієї школи.

Побудова підручника та його зміст певною мірою зберігають вітчизняні традиції викладання теорії держави і права, але трансформують їх відповідно до особливостей концептуального бачення загальнотеоретичної юриспруденції. Новаційність структури підручника виявляється не тільки в оновленні розділів, підрозділів, основних питань тем, але й у відмінній від традиційних побудов подібних підручників послідовності їх розташування й описання в тексті. Так, основними його розділами-темами є пролегомени права і держави; догма права; дія права; результативність права; статика і динаміка держави; право, держава і цивілізація.

Судити щодо доцільності запропонованої побудови та подання навчального матеріалу можливо з різних точок зору, але найголовнішим є те, наскільки авторам підручника вдалося в цьому підручнику реалізувати концептуальні засади одеської науково-педагогічної школи загальнотеоретичної юриспруденції, систематизувати результати наукових досліджень, адаптувати їх до особливостей сприйняття студентами.

Саме в цьому сенсі підручник виділяється з-поміж інших не тільки оригінальністю авторської «задумки», але й станом ї наукової розробки та забезпечення, оптимальним описанням і переводом складної та специфічної за природою «матерії» наукового пошуку в зрозумілий для студентів навчальний матеріал. Традиційність і новаційність в теоретичному мисленні, реалізація концепції загальнотеоретичної юриспруденціï в побудові та змістовному наповненні підручника проглядається у виокремленні статики та динаміки права і держави, їх антропологічному, 
аксіологічному й цивілізаційному та інших вимірах, розрізненні та єдності їх історії та сучасності, акцентуації їх соціального значення та ефективності, плюралістичності розуміння права, держави, їх взаємозв'язку, використанні наукових знань з інших наукових і навчальних дисциплін, зв'язку з практикою, досвідом інших країн тощо.

Значення цього підручника в розвитку одеської науково-педагогічної школи загальнотеоретичної юриспруденції полягає й в тому, що досвід його підготовки, результати, сприйнятті іншими вченими, педагогами та студентами, у свою чергу, зумовили доцільність і спрямованість нових наукових розвідок, які здійснювалися і здійснюються представниками цієї школи в межах власних наукових інтересів і наукових позицій, а також нових форм їх систематизації.

Знову таки, розширення площини наукового осягнення загальнотеоретичної юриспруденції, збереження традиції концептуального бачення загальнотеоретичної юриспруденції, виявлення нових ракурсів осмислення і формування новацій у їх дослідженні потребувало дещо іншої наукової систематизації та розгортання.

Напевно, якась зумовленість є в тому, що після підручника «Загальнотеоретична юриспруденція» авторами цієї школи було підготовлено та видано у 2012 колективну монографію «Актуальні грані загальнотеоретичної юриспруденції», у якій у систематизованому, доповненому та оновленому вигляді подане авторське бачення вирішення таких проблем держави і права та їх пізнання, як аксіометрія та аксіосфера держави i права, особливості правових цінностей у різних традиціях, антропологічний вимір міфів і їх значення як джерел права, особливості слов'янської правової культури, герменевтики в праві, мовного, міського та інших просторів права, держави і громадянського суспільства, а також новаційне бачення правового порядку, правового контрактивізму, інформаційної функції права, правових аспектів військової служби, правового мислення, правової допомоги тощо.

Про органічний зв'язок цих видань свідчить і виокремлення в окремий розділ питань, які стосуються розвитку юридичної освіти та викладання загальнотеоретичної юриспруденції, зокрема ii методологічного призначення, класичної юридичної освіти та їі розвитку, творчого характеру юридичної педагогіки, застосування юридичних технологій у підготовці юристів, особливостей викладання навчальних дисциплін «мова українського права», «церковне право», «військове право» та інших.

У цій монографії прослідковується спроба надати нової цілісності, взаємопов'язаності плюралізму варіацій і площин розкриття «панорами» загальнотеоретичної юриспруденції, яка спонукала до їх відповідного переосмислення, виявлення та дослідження нових аспектів, зв'язків, ракурсів, проблем, властивостей, або додаткового визнання через публікації в авторитетних виданнях, зокрема іноземною мовою.

Так, нові обрії надаються у 2013-2014 роках Ю.М. Оборотовим подальшій концептуалізації та розв'язанню вже раніше окреслених про- 
блем: загальнотеоретичної юриспруденції, своєрідності українського права, його просторової зумовленості (місцерозвитку) і цивілізаційної ідентифікації, розгортання методології юриспруденції, взаємовпливів теоретичного «образу» держави та реалій ії існування, такій властивості права, як надійність. Иого статті публікуються у всеукраїнських виданнях «Право України», «Юридичний вісник», колективній монографії НАПрУ «Правова доктрина України» та інших.

Подібні дослідження, результати яких оприлюднюються в наукових статтях, тезах наукових конференцій тощо, здійснюються й іншими представниками школи. Результатом колективного осмислення новаційної орієнтації загальнотеоретичної юриспруденції як сучасної теорії держави і права стала монографія «Креативність загальнотеоретичної юриспруденції (2015), у передмові до якої її автори підкреслюють, що в сучасних умовах і напрямах розвитку української юриспруденції «досить характерним виступає дослідницький запал учених Одеської школи права, які представляють загальнотеоретичну юриспруденцію, розробки яких усе частіше оформлюються в концептуальні ідеї, методологічні принципи, правові та державні цінності і норми, які відповідають сучасній епосі постмодерну і особливостям існування в ній суверенної України».

Використовуючи розуміння креативності сучасної юриспруденції, поданої в цій монографії, і враховуючи зазначене вище, можна стверджувати, що саме для одеської науково-педагогічної школи загальнотеоретичної юриспруденції притаманне «звільнення юридичних досліджень від догматизованості стереотипів правового мислення, безпосереднє звернення до традицій, норм та інститутів правової спадщини та їх творче використання в умовах нового часу, відстоювання власної (української) правової ідентичності, державної цілісності і самого управлінського місцевого різноманіття».

Концептуалізація загальнотеоретичної юриспруденції в інтерпретації цієї школи не є догматичною, закритою, завершеною; навпаки, є дієздатною і внутрішньо орієнтованою на подальший розвиток. Не тільки за результатами наукових досліджень, які здійснюються представниками цієї школи, але й у наукових розвідках інших науковців, які здійснюють свої наукові пошуки в концептуальному полі загальнотеоретичної юриспруденції чи під ії впливом, закладаються перспективні напрями подальших досліджень, але вони стають основою наукового прогнозування, планування наукових досліджень.

Так, у планах наукових досліджень академії та їі кафедри теорії держави і права (і не тільки них) передбачено низку заходів, спрямованих на подальший розвиток загальнотеоретичної юриспруденції, яка вже перестає бути лише тільки концептуальним баченням теорії держави і права, а набуває властивостей конкретизованого, внутрішньо узгодженого, методологічно вивіреного і практично значущого наукового знання. Прикладом цього можуть бути напрями наукових досліджень, які реалізуються в межах дисертаційних досліджень на здобуття наукових ступенів 
кандидата та доктора юридичних наук: держава і право в працях О.В. Сурілова, державно-приватне партнерство, класифікаціі правових інститутів, аналіз властивостей правого життя, правової політики, електронної держави, інститутів та функцій сучасної держави, правової нормативності українського права, інтегративної правової системи, джерел процесуального права України, дуалізму сучасного права, контрактивізації механізму дії права, трансформації держави в умовах глобалізації, правових тезаурусів та інших проблем загальнотеоретичної юриспруденції.

\section{Висновки.}

Безумовно, не можна сказати, що запропоноване для розгляду наукове бачення змістовного наповнення і перспектив розвитку теорії держави і права є єдино можливим і доцільним, як, власне, і сама концепція загальнотеоретичної юриспруденції; утім, іï представники не претендують на це.

Сьогодні на пострадянському просторі важко визначити якусь іншу наукову школу розуміння загальної теорії держави і права, яка б мала такий рівень наукового забезпечення, масив публікацій, була чисельною за учасниками, характеризувалася цілісністю, концептуальністю та плюралізмом сприйняття загальної теорії держави і права, на такому рівні запроваджена в навчальний процес, визнана науковою спільнотою в іiі концептуальному баченні загальнотеоретичних проблем осмислення та розвитку держави і права, найбільш повно охоплювала таку форму інституціоналізації науки, як наукова школа, мала перспективи подальшого свого розвитку тощо. I в цьому аспекті одеська наукова школа загальнотеоретичної юриспруденції може і повинна слугувати прикладом, зразком, моделлю для інших шкіл.

Можна лише побажати науковцям цієї школи та їі прихильникам творчої наснаги та подальших успіхів, прагнення зберігати власні традиції та наповнювати свої наукові дослідження новаціями.

На завершення, враховуючи значний обсяг праць, у яких висвітлюються результати концептуалізації загальнотеоретичної юриспруденції представниками одеської науково-педагогічної школи, доцільно навести лише основні праці, у яких найбільш повно відбиваються такі їі властивості, як колективність і креативність:

\section{Література}

1. Общетеоретическая юриспруденция: учебный курс : [учебник] / под. ред. Ю.Н. Оборотова. - О. : Фенікс, 2011. - 436 с.

2. Актуальні грані загальнотеоретичної юриспруденції : [монографія] / [Ю.М. Оборотов, В.В. Завальнюк, В.В. Дудченко та ін.] ; за ред. Ю.М. Оборотова. - О. : Фенікс, 2012. - 492 с.

3. Креативність загальнотеоретичної юриспруденції : [монографія] / [Ю.М. Оборотов, В.В. Завальнюк, В.В. Дудченко та ін.] ; за ред. Ю.М. Оборотова. - О. : Фенікс, 2015. - 488 с. 


\section{А нот а ці я}

Тихомиров О. Д., Горобець K. В. Загальнотеоретична юриспруденція: традиції та новації Одеської науково-педагогічної школи Юрія Миколайовича Оборотова. - Стаття.

Стаття присвячена наукознавчому виміру становлення школи загальнотеоретичної юриспруденції в Національному університеті «Одеська юридична академія». Виявлені методологічні, педагогічні та наукові підвалини іiі формування та розвитку. Окрема увага приділена питанням напрямів наукових досліджень школи загальнотеоретичної юриспруденції та їі перспективам у дискурсивному полі вітчизняної юриспруденції.

Ключові слова: загальнотеоретична юриспруденція, одеська школа права, теорія держави і права.

\section{Ан н от а и я}

Тихомиров A. Д., Горобец, K. В. Общетеоретическая юриспруденция: традиции и новации Одесской научно-педагогической школы Юрия Николаевича Оборотова. Статья.

Статья посвящена науковедческому измерению становления школы общетеоретической юриспруденции в Национальном университете «Одесская юридическая академия». Выявляются методологические, педагогические и научные основы ее формирования и развития. Особое внимание уделено вопросам направлений научных исследований школы общетеоретической юриспруденции и ее перспективам в дискурсивном поле отечественной юриспруденции.

Ключевые слова: общетеоретическая юриспруденция, одесская школа права, теория государства и права.

\section{S u m m a r y}

Tikhomirov O. D. Gorobetc $K$. V. General theoretical law: tradition and innovation of Odessa scientific-educational school of Yuriy Nikolayevich Oborotov. - Article.

The article is devoted to the doctrinal measurement of becoming of general theoretical jurisprudence school at the National University "Odessa Law Academy". The methodological, pedagogical and scientific foundations of this school as well as its formation and development are highlighted. Special attention is paid to areas of research of the school of general theoretical jurisprudence and its perspectives in the discursive field of domestic legal doctrine.

Key words: general theoretical jurisprudence, Odessa School of Law, theory of state and law. 